\title{
MANAJEMEN PEMBELAJARAN PONDOK PESANTREN
}

\author{
Deviana Ika Maharani \\ M. Huda A.Y \\ Imron Arifin \\ E-mail: maharanideviana@gmail.com \\ Universitas Negeri Malang Jl. Semarang No. 5 Kota Malang
}

\begin{abstract}
Focus in this research is planning, implementation, and evaluation of learning islamic boarding school Darur Roja'. This study used qualitative methode; by case study a site design; Researchers as an instrument of this study; Data sources of this study are the vice principal of caregiver islamic boarding school, the foundation's president, management, teacher and student; data were collected through indepth interview, observation, and documentation. Islamic boarding school Darur Roja' learning plan in principle include the syllabus and learning implementation plan but not yet documented. implementation of the learning process is done every Saturday until Thursday. Teacher make methods of delivery of material wear Sorogan and wetonan and the end discussion. Evaluation of learning using formative evaluation is in the form of assessment test eonducted after the completion of subject studied students and summative.
\end{abstract}

Keyword: learning management, islamic boarding school.

\begin{abstract}
Abstrak: Fokus pada penelitian ini adalah perencanaan, pelaksanaan, dan evaluasi pembelajaran Pondok Pesantren Darur Roja'. Pendekatan kualitatif dengan rancangan studi kasus tunggal; peneliti sebagai instrumen; sumber data meliputi pengasuh pondok pesantren, ketua yayasan, pengurus, ustadz dan santri pondok pesantren; teknik pengumpulan data dengan wawancara, observasi, dan dokumentasi. Perencanaan pembelajaran Pondok Pesantren Darur Roja' secara prinsip dilengkapi silabus dan Rancangan Pelaksanaan Pembelajaran (RPP) tetapi belum didokumentasikan, Pelaksanaan proses belajar mengajar dilaksanakan setiap hari Sabtu-Kamis, ustadz menyampaikan materi pelajaran dengan menggunakan metode penyampaian materi sorogan dan wetonan, dan diakhiri dengan tanya jawab. Evaluasi pembelajaran menggunakan evaluasi formatif yaitu penilaian berupa tes yang dilakukan setelah satu pokok bahasan selesai dipelajari santri dan evaluasi sumatif.
\end{abstract}

Kata kunci: manajemen pembelajaran, pondok pesantren.

Pandangan ajaran Islam, segala sesuatu harus dilakukan secara rapi, benar, tertib, dan teratur. Proses-prosesnya harus diikuti dengan baik. Sesuatu tidak boleh dilakukan secara asal-asalan. Mulai dari urusan terkecil seperti mengatur urusan rumah tangga sampai dengan urusan terbesar seperti mengatur sebuah negara semua memerlukan pengaturan yang baik, tepat dan terarah dalam bingkai sebuah manjemen agar tujuan yang hendak dicapai bisa diraih dan bisa selesai secara efisien dan efektif. Demikian pula halnya dengan pengelolaan sebuah lembaga pendidikan, manajemen merupakan salah satu kunci sukses, karena sangat menentukan kelancaran kinerja lembaga yang bersangkutan. Hal ini berarti manajemen yang baik dapat menunjang untuk menghasilkan lembaga pendidikan yang berkualitas tinggi. Sebaliknya, buruknya implementasi manajemen dapat pula berdampak pada rendahnya kualitas lembaga pendidikan tersebut.

Belajar menurut Huda (2010:84) adalah proses terbentuknya tingkah laku baru sebagai hasil respons individu terhadap lingkungannya, dengan kata lain belajar adalah perubahan dalam tingkah laku dan cara seseorang berbuat dalam situasi tertentu. Pengertian pembelajaran tersebut dapat diartikan sebagai usaha kearah 
pencapaian tujuan melalui aktifitas orang lain atau membuat sesuatu untuk dikerjakan orang lain, berupa peningkatan minat, perhatian, kesenangan dan latar belakang peserta didik untuk meningkatkan kualitas peserta didik serta mengarah kepada pengembangan gaya hidup dimasa mendatang. Para ahli seperti Ambarita (2006:72) mengemukakan manajemen pembelajaran berarti kemampuan guru dalam mendayagunakan sumber daya yang ada, melalui kegiatan menciptakan dan mengembangkan kerja sama, sehingga terbentuk pembelajaran untuk mencapai tujuan pendidikan di kelas secara efektif dan efisien.

Suatu kegiatan yang baik tentunya diawali dengan perencanaan yang jelas. Sagala (2012:49) menyatakan bahwa perencanaan merupakan suatu hasil yang telah disepakati secara bersamasama oleh personel-personel tentang apa yang harus dilakukan untuk kedepannya. Hal ini berkaitan dengan identifikasi kebutuhan yang akan dicapai oleh suatu lembaga maupun institusi.Herujito (2001:89) juga menjelaskan bahwa dalam merumuskan perencanaan ada empat langkah antara lain:1)menentukan tujuan; 2) menentukan situasi sekarang; 3) menentukan bantuan atau rintangan; dan 4) mengembangkan seperangkat tindakan. Berdasarkan penjelasan dari kedua pendapat tersebut, pendapat ditarik kesimpulan bahwa suatu perencanaan didasarkan pada langkah-langkah yang ditempuh untuk mencapai suatu tujuan. Salah satunya dengan mengiidentifikasi kebutuhan dan lamanya suatu kegiatan. Seperti pendapat Effendi (2009:57) menjelaskan bahwa perencanaan pembelajaran juga memerlukan suatu perencanaan, perencanaan pembelajaran tersebut bisa dengan melihat yaitu tingkat satuan waktu pembelajaran yaitu: satuan waktu harian, catur wulan, atau semester, atau bahkan tahunan, dengan begitu dalam menentukan satuan waktu pembelajaran, pengelolaan proses pembelajaran dapat berjalan sesuai waktu yang telah ditentukan.

Sesuai dengan Depdiknas (2004:16) Pelaksanaan pembelajaran adalah "proses kegiatan belajar peseta didik sesuai dengan rencana yang telah ditetapkan untuk mencapai penguasaan kompetensi". Untuk mencapai penguasaan komptensi-komptensi oleh peserta didik tentunya seorang guru akan menentukan beberapa strategi, metode dan pendekatan dalam pelaksanaan pembelajaran. Strategi merupakan kegiatan merancang taktik menyeluruh untuk menghadapi masalah-masalah dalam mencapai tujuan, sedangkan metode adalah cara yang bersifat khusus. Seperti halnya menurut Unesco (dalam Sanjaya, 2008:97) menjelaskan bahwa karakteristik pembelajaran dibagi menjadi 4 yaitu antara lain:

a) Learning to know, belajar tidak hanya berorientasi pada hasil belajar, namun harus berorientasi pada proses belajar. Hal demikian adalah belajar tidak hanya terbatas disekolah.

b) Learning to do, belajar merupakan kumpulan pengetahuan yang dicapai seseorang, belajar bukan hanya melihat atau mendengar. Belajar mempunyai tujuan untuk menguasai kompetensi-kompetensi yang diinginkan dalam melakukan sesuatu.

c) Learning to be, belajar merupakan proses pembentukan manusia yang menjadi dirinya sendiri. Maksudnya adalah belajar ialah mengaktualisasikan dirinya sendiri sebagai individu sebagai manusia yang mempunyai tanggung jawab apa yang dilakukan.

d) Learning to live together, ialah belajar untuk bekerjasama. Adanya bekerja sama manusia dibentuk menjadi manusia yang tidak individual. Karena manusia adalah makhluk sosial yang tidak dapat hidup sendiri.

Karakteristik belajar dapat disimpulkan bahwa suatu kegiatan belajar yang tidak berorientasi pada hasil dan mempunyai tujuan untuk menguasai kompetensi-kompetensi yang diinginkan dengan tanggung jawabnya untuk bekerja sama dalam mencapai tujuan yang diinginkan.

Pembelajaran sendiri memerlukan evaluasi dimana dalam evaluasi pembelajaran tersebut merupakan proses memberikan penilaian, pengukuran terhadap pengambilan keputusan. Menurut Setyosari (2001:20) "Evaluasi pembelajaran merupakan proses untuk menentukan dan menggunakan tekhnik untuk mengidentifikasi kelemahan-kelemahan yang ada atau yang terjadi dalam pembelajaran". Sedangkan Gronlund (dalam Huda, 2010:85) berpendapat bahwa prinsip dasar tes prestasi belajar siswa meliputi enam hal yaitu mengukur tujuan belajar, mewakili semua tujuan dan 
seluruh materi pelajaran, membuat itemitem yang sesuai, sesuai dengan maksud penggunaannya, reliabel dan menafsirkan secara cermat, meningkatkan belajar siswa. Upaya mengidentifikasi kebutuhan-kebutuhan menurut Kaufman (dalam Huda, 2010:33) berarti menganalisis kesenjangan antara dua kutub, yakni "antara dimana sekarang" dan "dimana kita seharusnya berada". Dalam melakukan asesmen kebutuhan kependidikan untuk mencapai mutu pendidikan, terdapat tiga komponen yaitu peserta didik, orang tua dan anggota masyarakat, tenaga pendidik dan komponen-komponen yang terlibat dalam proses kependidikan.

Selain itu perencanaan pembelajaran juga perlu diperhatikan pada sebuah pondok pesantren karena perencanaan akan mempengaruhi kualitas lulusan Menurut PP No.19/2005 tentang Standar Nasiona 1 Pendidikan pada Pasal 20 disebutkan, "perencanaan proses pembelajaran meliputi silabus dan rencana pelaksanaanpembelajaran yang memuat sekurang -kurangnya tujuan pembelajaran, materiajar,metode pengajaran, sumber belajar, dan penilaian hasil belajar".

Berdasarkan pendapat di atas, dapat disimpulkan Pondok Pesantren dapat selain sebagai tempat untuk mempelajari dan menyebarkan agama Islam, dapat juga digunakan sebagai lembaga pendidikan untuk mempelajari ilmu umum, kegiatan sosial dan ekonomi dengan mendirikan koperasi yang dikelola para santri, serta sebagai pewarisan nilai tradisi budaya Islam dan budaya di daerah setempat dengan berpacu pada rencana pembelajaran yang dijalankan di pondok pesantren. Sa'id (2012), unsur-unsur yang harus dipenuhi Pondok Pesantren adalah adanya pemondokkan atau asrama, masjid atau mushola, pengajian kitab kuning, santri, dan kyai atau pengasuh.

Berdasarkan pendapat tersebut, setiap Pondok Pesantren mengembangkan manajemen pembelajarannya sendiri dan menetapkan institusi-institusi pendidikannya sendiri dalam rangka merespon tantangan dari luar. Mencermati beberapa pendapat di atas, dapat ditarik kesimpulan unsur-unsur pondok pesantren adalah kyai atau ustad sebagai pangajar, santri sebagai subjek yang belajar, masjid sebagai tempat ibadah sekaligus ruang belajar, kitab sebagai rujukan materi pelajaran, sistem atau aturan yang tertib dengan kepemimpinan kharismatik seorang kyai atau ustad. Keberadaan kyai sebagai pemimpin pesantren, ditinjau dari peran dan fungsinya dapat dipandang sebagai fenomena kepemimpinan yang unik, karena selain memimpin lembaga pendidikan Islam yang tidak hanya bertugas menyusun kurikulum, membuat tata tertib, merancang sistem evaluasi sekaligus melaksanakan proses belajar mengajar yang berkaitan dengan ilmu agama yang diasuhnya, dia juga sebagai pembina, pendidik umat serta pemimpin rakyat. Kondisi tersebut menuntut seorang kyai dalam peran dan fungsinya untuk memiliki kebijaksanaan dan wawasan, terampil dalam ilmu-ilmu agama, mampu menananmkan sikap dan pandangan serta wajib menjadi top figur (teladan) sebagai pemimpin yang baik, lebih jauh lagi kyai di pesantren dikaitkan dengan kekuasaan supranatural yang dianggap figur ulama adalah pewaris risalah kenabian, sehingga keberadaanya dianggap memiliki kedekatan hubungan dengan Tuhan (Arifin, 2010:45). Sedangkan ciri-ciri Pondok Pesantren yaitu adanya hubungan yang akrab antara kyai atau ustad dengan santrinya. Hubungan emosional ini dapat tercipta karena keduanya tinggal di tempat yang sama sehingga interaksinya lebih intens terjalin, Kepatuhan santri terhadap kyai atau ustad. Ketaatan dan penghormatan ini dapatterjaga karena salah satu adab dalam menuntut ilmu adalah harus menghormati guru dan tidak menentangnya. Ada anggapan jika santri menentang kyai atau ustad akibatnya ilmu yang diperoleh tidak berkah dan sulit dipahami santri, Hidup hemat dan sederhana. Hidup mewah hampir tidak ditemukan disana. Bahkan sedikit santri yang hidupnya terlalu sederhana atau terlalu hemat sehingga kurang memperhatikan pemenuhan gizi, Kemandirian sangat terasa di Pondok Pesantren. Bentuk kemandirian ini dapat dilihat dari kemandirian finansial dengan membuka usaha, berkebun, atau ternak hewan. Meskipun tidak semua pesantren demikian tetapi masih dapat ditemui di Jawa. Kemandirian aktivitas santri seperti mencuci pakaian, memasak, membersihkan kamar dan pekarangan. Kesemuanya dituntut agar santri dapat mengatur waktu dengan baik, Jiwa tolong -menolong dan suasana persaudaraan (ukhuwah Islamiyah). Banyak sekali kegiatan yang dilakukan bersama di pondok pesantren seperti sholat berjama'ah, proses belajar mengajar di kelas, membersihkan 
masjid dan pondok. Aktivitas tersebut sangat menopang suasana persaudaraan dan keakraban diantara santri, disiplin sangat dianjurkan. Hukuman melanggar biasanya diberikan sanksisanksi edukatif. Keprihatinan untuk mencapai tujuan mulia dilakukan melalui kebiasaan puasa sunat, zikir, i’tikaf, sholat tahajud atau bentuk meneladani kyai atau ustad yang menonjolkan sikap zuhd (tidak terpikat dengan kenikmatan dunia). Pemberian ijazah dengan mencantumkan nama yang diberikan kepada santri yang lulus dalam menempuh proses belajar mengajar di pondok pesantren. Hal ini menandakan restu kyai atau ustad kepada santri untuk mengajarkan ilmu yang telah diperolehnya.

Menyadari hal tersebut, penelitian ini memiliki manfaat bagi pengasuh Pondok Pesantren Darur Roja' untuk menjadikan penelitian ini sebagai hasil evaluasi dan perbaikan terhadap manajemen pembelajaran, bagi ustadz dan ustadzah dapat menggunakan sebagai bahan evaluasi dan perbaikan pada pelaksanaan pembelajaran, hasil penelitian ini dapat menambah referensi tentang manajemen pembelajaran, dan bagi peneliti lain dapat digunakan sebagai pertimbangan penelitian yang serupa.

\section{METODE}

Penelitian ini menggunakan pendekatan kualitatif dengan rancangan penelitian deskriptif. Berdasarkan rancangan penelitian yang dilakukan, kehadiran peneliti sangat diperlukan karena peneliti berperan sebagai instrument kunci dalam menggali informasi secara mendalam dan detail.

Penelitian ini dilakukan di Pondok Pesantren Darur Roja' Blitar yang berada di jalan KH. Wahid Hasyim No. 1 Desa Selokajang Kecamatan Srengat Kabupaten Blitar. Sumber data dalama penelitian ini menggunakan data primer dan sekunder. Data primer meliputi menggali informasi pengasuh Pondok Pesantren, Ketua Yayasan, sstadz, pengurus dan santri Pondok Pesantren Darur Roja'. Sementara itu data sekunder yaitu berupa dokumentasi, dimana dokumen tersebut kemudia akan dianalisis dan dijadikan sebagai bukti pendukung.

Prosedur pengumpulan data dalam penelitian ini menggunakan tiga teknik yaitu wawancara, observasi (pengamatan), dan dokumentasi Sedangkan untuk menganalisis data menggunakan tiga tahap yaitu tahap reduksi data, penyajian (display) data, dan verifikasi (penyimpulan) data. Tahapan tersebut digunakan untuk memilih dan menyaring informasi yang sesuai dengan fokus penelitian sehingga dapat disimpulkan sesuai dengan informasi yang diperoleh. Pengecekan data juga diperlukan dalam penelitian ini yaitu digunakan untuk memastikan kebenaran dari informasi yang diperoleh mengenai apa yang telah diproleh oleh peneliti. Pengecekan keabsahan data penelitian ini meliputi tiga kegiatan yaitu, perpanjangan keikutsertaan, triangulasi, dan ketekunan pengamatan. Studi ini juga memiliki tahapan dalam proses penelitian antara lain tahap persiapan, tahap lapangan, dan tahap penulisan lapangan.

\section{HASIL}

Pondok Pesantren Darur Roja' menginventarisir materi pelajaran dan membagi dalam struktur pembelajaran tersendiri dengan harapan mampu mencetak santrinya menjadi ustadz dan sosok pengembang agama di masyarakat. Pondok Pesantren Darur Roja' termasuk jenis pendidikan keagamaan yang di selenggarakan dalam jalur pendidikan nonformal, mempunyai cara tertentu dalam penyusunan perencanaan pembelajaran.

Adapun format kurikulum yang dibuat Pondok Pesantren Darur Roja' yaitu: (1) Kurikulum ta'limi atau teoritis meliputi pengantar ilmu orisinil keislaman seperti aqidah, fiqih, akhlak, tafsir Qur'an, hadist, dan tarikh Nabi; (2) Kurikulum tarbawi atau pembentukan kepribadian meliputi shalat malam, puasa sunnah, membaca Al Qur'an dan maknanya, pendalaman kitab, manajemen Qolbu dan muhasabah (evaluasi); dan (3) Kurikulum praktik langsung menjadi ustadz yaitu dengan latihan memaknai kitab, dan praktik langsung menjadi ustadz pada kegiatan madrasah sesuai dengan tingkatan yang dipelajari.

Selain kurikulum (pengurus Pondok Pesantren Darur Roja' menyebutnya demikian), komponen penting dalam perencanaan pembelajaran terdiri dari silabus, dan Rancangan Pelaksanaan Pembelajaran (RPP), program tahunan, program semester, desain pembelajaran, metode pembelajaran, penilaian, dan kontrol 
untuk mengetahui pencapaian indikator keberhasilan peserta didik adalah komponen yang perlu dilengkapi untuk menciptakan jalur pendidikan nonformal yang bermutu.

Tahapan proses belajar mengajar yang dilakukan Pondok Pesantren Darur Roja' yaitu kegiatan awal, Pembukaan dimulai dengan ucapan salam dilanjutkan doa sebelum pelajaran dimulai yang dipimpin oleh ustad atau pengajar. Pretest terkadang dilakukan ustad untuk mengetahui kefahaman santri terhadap materi pelajaran yang diberikan pekan lalu, sekaligus mengulang pelajaran secara singkat sebelum masuk ke materi inti. Kegiatan inti, Ustadz langsung menjelaskan ke pokok materi pelajaran. Kegiatan tidak mulai dengan menjelaskan tujuan pengajaran dan pokok-pokok materinya yang akan diberikan setiap pertemuan. Hal ini disebabkan karena ustad tidak mempunyai silabus dan RPP. Metode penyampaian materi yang digunakan ceramah dan interaktif karena karakteristik peserta didik adalah orang dewasa, maka menggunakan metode andragogi atau pendidikan untuk orang dewasa yang lebih interaktif dan ditutup dengan tanya jawab. Kegiatan pembelajaran, para ustad atau pengajar menggunakan alat bantu seperti laptop, LCD, papan tulias, spidol, dan makalah yang dibagikan ke para santri untuk memudahkannya dalam memahami mata pelajaran. Ustad menyimpulkan materi pelajaran. Biasanya ditutup dengan meringkas beberapa poin materi yang disampaikan. Kegiatan akhir, membuka sesi tanya jawab kepada para santri apalagi belum jelas materi yang disampaikan. Ustadz memberitahu materi yang akan dibahas dan dikaji pada pertemuan berikutnya. Menutup proses belajar mengajar dengan doa bersama penutup majelis ilmu. Ustadz mengucapkan salam penutup.

Bentuk evaluasi pembelajaran dapat dibedakan menjadi evaluasi formatif dan evaluasi sumatif. Evaluasi formatif adalah penilain berupa tes (soal-soal atau pertanyaan) yang diselenggarakan setelah satu pokok bahasan selesai dipelajari peserta didik. Evaluasi sumatif adalah penilaian berupa tes yang dilakukan setelah proses belajar mengajar selesai dalam jangka waktu tertentu, misalnya satu semester atau satu caturwulan. Sistem penilaian mata pelajaran yang digunakan di pesantren ini ada yang dilakukan setiap selesai mata pelajaran, tetapi kebanyakan dilaksanakan setiap selesai semester. Penilaian per bab mata pelajaran dan pertengahan atau mid semester tidak sering dilakukan karena pengajar terlihat tidak mempunyai target standar kompetensi yang jelas saat mengajar. Hal ini terlihat dari tidak adanya silabus dan RPP satu pun yang menjadi panduan ustadz.

\section{PEMBAHASAN}

Perencanaan pembelajaran akan mempengaruhi kualitas lulusan satuan pendidikan, oleh sebab itu, pemerintah membuat peraturan pemerintah tentang standar nasional pendidikan untuk mengatur pengelolaan pendidikan. Menurut PP No.19/2005 tentang Standar Nasiona 1 Pendidikan pada Pasal 20 disebutkan, "perencanaan proses pembelajaran meliputi silabus dan rencana pelaksanaan pembelajaran yang memuat sekurang-kurangnya tujuan pembelajaran, materi ajar, metode pengajaran, sumber belajar, dan penilaian hasil belajar ". Pondok Pesantren Darur Roja' termasuk jenis pendidikan keagamaan yang diselenggarakan menggunakan jalur pendidikan nonformal. Fungsi dari jalur pendidikan nonformal menurut UU No. 20/ 2003 tentang Sistem Pendidikan Nasional pada Pasal 26 disebutkan "pendidikan nonformal diselenggarakan bagi warga masyarakat yang memerlukan layanan pendidikan yang berfungsi sebagai pengganti, penambah, dan atau pelengkap pendidikan formal dalam rangka mendukung pendidikan sepanjang hayat".

Pondok Pesantren Darur Roja' mengacu amanat konstitusi di atas, proses perencanaan dan pengembangan pembelajarannya dapat dibuat sesuai dengan potensi dan kemampuan pesantren setempat tanpa ada panduan yang baku, sehingga dapat dikatakan Pondok Pesantren Darur Roja' dapat merencanakan, melaksanakan, dan mengevaluasi pembelajaran sendiri. Inilah mungkin yang menjelaskan kenapa Pondok Pesantren Darur Roja' hanya menginventarisir mata pelajaran yang dibutuhkan untuk diajarkan tanpa membuat silabus dan Rancangan Pelaksanaan Pembelajaran, karena keduanya merupakan bagian dari perencanaan pendidikan yang melekat dalam jalur pendidikan formal. Silabus dan RPP tersebut menurut pengurus Pondok Pesantren Darur Roja' sudah masuk 
dalam format kurikulum pendidikan yang dibuat, hanya saja belum sempat dituliskan.

Pembelajaran Pondok Pesantren Darur Roja' dilakukan dengan tiga tahap yaitu kegiatan awal, kegiatan inti dan kegiatan akhir. Pondok pesantren ini dijadikan sebagai tempat tinggal peserta didik yang menempuh pendidikan di SD, SMP, dan SMA serta santri lain yang tidak bersekolah. Sesuai dengan pendapat Hasyim (dalam Walsh, 2011) yang menjabarkan usur pondok pesantren yaitu Pondok yang berfungsi sebagai tempat tinggal santri, pengajar terkenal dengan sebutan kyai atau ustad tidaklah sembarangan orang, tetapi orang yang ditunjuk oleh institusi atau yayasan pondok pesantren karena mempunyai pengetahuan agama Islam yang mendalam, santri yaitu pelajar yang belajar di pondok pesantren, terdapat Masjid sebagai tempat melaksanakan aktivitas keagamaan, Kitab sebagai buku pegangan dan bacaan untuk mendalami materi setelah proses belajar mengajar selesai. Pondok pesantren Darur Roja' merupakan pondok pesantren salafiyah yang pembelajarannya mengacu pada kitab sepserti kitab kuning dan metode pembelajaran yang digunakan masih klasikal dengan metode sorogan dan wetonan.

\section{KESIMPULAN DAN SARAN}

\section{Kesimpulan}

Proses perencanaan pembelajaran dilakukan ustadz pendiri tanpa melibatkan staf pengajar lain, dan belum mengalami perubahan sampai saat ini. Dimulai dari menulis daftar materi yang akan diberikan dan dibagi ke dalam dua semester. Rinciannya ada kurikulum ta'limi atau materi teoritis, kurikulum tarbawi berorientasi pada pembentukan kepribadian santri, dan kurikulum praktik langsung menjadi ustadz. Pondok Pesantren Darur Roja' merupakan jenis pendidikan keagamaan yang diselenggarakan melalui jalur pendidikan nonformal sehingga silabus dan Rancangan Pelaksanaan Pembelajaran (RPP) tidak harus terstruktur seperti di pendidikan formal. Silabus dan RPP secara prinsip sudah ada, tetapi belum terdokumentasikan dengan baik. Pelaksanaan proses belajar mengajar dilakukan setiap hari kecuali hari jumat, pembelajaran dilakukan mulai pagi hari diawali dengan jamaah sholat subuh dan diakhiri dengan belajar bersama pada malam hari.
Mata pelajaran disesuaikan setiap angkatannya. Ustad menyampaikan materi dengan metode sorogan wetonan dan metode klasikal. Pesantren ini menggunakan evaluasi formatif dan evaluasi sumatif. Evaluasi formatif dilakukan untuk mata pelajaran yang ada praktiknya dan dilakukan tes selesai setiap satu pokok bahasan. Evaluasi sumaif dilakukan setiap akhir semester.

\section{Saran}

Berdasarkan penelitian yang telah dilakukan di Pondok Pesantren Darur Roja' Blitar, maka saran yang dapat diberikan oleh peneliti bagi Pengasuh Pondok Pesantren Darur Roja' Blitar, hasil penelitian ini dapat ijadikan sebagai bahan evaluasi dan perbaikan terhadap manajemen pembelajaran, sehingga dapat meningkatkan kualitas prestasi santri. Bagi stadz dan ustadzah Pondok Pesantren Darur Roja', hasil penelitian ini dapat dijadikan sebagai bahan evaluasi dan perbaikan terhadap pelaksanaan pembelajaran, sehingga dapat meningkatkan inovasi dan kreativitas dalam pembelajaran. Bagi Ketua JurusanAdministrasiPendidikan Fakultas Ilmu Pendidikan Universitas Negeri Malang, hasil penelitian ini diharapkan bisa menambah referensi tentang manajemen pembelajaran. Bagi peneliti lain, hasil penelitian ini dapat dimanfaatkan bagi peneliti lain sebagai bahan pertimbangan untuk penelitian serupa, sertamengembangkannya lebih mendalam dan untuk bahan perbandingan antara teori yang sudah ada dengan kenyataan di lapangan.

\section{DAFTAR RUJUKAN}

Ambarita, A. 2006. Manajemen Pembelajaran. Jakarta: Departemen Pendidikan Nasional.

Arifin, I., Slamet, M. 2010. Kepemimpinan Kyai dalam Perubahan Manajemen Pondok Pesantren Tebuireng Jombang. Yogyakarta: Aditya Media.

Depdiknas. 2004. Kurikulum SMK Edisi 2004. Jakarta: Depdiknas.

Efendi, M. 2009, Kurikulum dan Pembelajaran: Pengantar Kearah Pemahaman KBK, KTSP, dan $S B I$. Malang. FIP Universitas Negeri Malang.

Herujito, Y. M. 2001. Dasar-Dasar Manajemen. Jakarta: Grasindo.

Huda, M, A.Y. 2010. Kajian Filosofis Otonomi Daerah Bidang Pendidikan. Malang: FIP Universitas Negeri Malang. 
Peraturan Pemerintah No. 19 tahun 2005 tentangStandar Nasional Pendidikan. (Online). (https://suryantara.ordpress.com/2011/09/13/ pp-no-19-tahun-2005-tentang-standar-nasionalpendidikan/). Diakses 30 Maret 2016.

Sa'id, M 2012.Pondok Pesantren Terpadu (Potret Ponpes Yanabi'ul Warrohmah. (Online). (http:// www.manubanat-kudus.sch.id/index.php/ pendidikan/121-pondok-pesantren-terpadu). Diakses 8 Maret 2016.
Sagala, S. 2012. Administrasi Pendidikan Kontemporer. Bandung: Alfabeta.

Sanjaya, W. 2008. Pembelajaran dalam implementasi kurikulum berbasis komptensi.Jakarta: Kencana Prenada Media group.

Setyosari, P. 2001. Rancangan Pembelajaran Teori dan Praktek. Malang: Elang Mas. 